\title{
Sterner Response Toward Rape in line with Islamic Law: Special Reference to Pakistan
}

\author{
Shahzeb Shahid ${ }^{*}$ \\ ${ }^{1}$ Punjab University, Pakistan \\ *Corresponding Email: sahzebshahid004847@gmail.com
}

Abstract: This paper tends to examine the nature of rape crime under Islamic law in order to take sterner action against this crime in line with Islamic law. As the Holy Quran does not directly deal with rape crime, for this reason, there is a wide range of disagreement among jurists regarding the issue of rape crime. Rape is not a single dimension issue, therefore, this paper is meant to shed light on issues related to rape such as whether or not rape is a separate crime? When does sexual intercourse amount to rape? What does Islam prescribe punishment for a person who is coerced to commit rape? Does Islam permit abortion for raped women? Why marital rape does not exist in Islam? Whether rapist may be awarded punishment of lashes, Imprisonment or death as t'azir or syasah? This paper finds out what Zina (fornication) is under Islamic law because in Islamic jurisprudence only coerced zina is regarded as rape. Thus, this paper is classifying rape in the same category as Zina. By classifying rape as a subset of Zina can only sort out the juridical issues that are emanating from coerced Zina. However, Some modern scholars put rape in a category of Hirabbah crime in order to circumvent the strict evidentiary procedure of Zina(fornication) crime. This paper depicts that there is no need to put rape in the domain of Hirabah because Islamic law permits the ruler or legislation to award punishment of lashes or death as Tazir or Syasah without waiting for the four pious Muslim male eyewitness and inflicting Hadd of Qadaf(slander) to the complainant. Finally, this paper is exploring the options that may be taken in order to nip this crime in the bud.

Keywords: Zina; Rape; Non-consensual sexual intercourse, marital rape; coercion, Syasah, Tazir 


\section{S. Shahid}

\section{A. Introduction}

Rape is regarded by many as gender issue in society, as it is perpetrated by men against women. It is a serious crime because it disturbs social order, human lineage and also affects women's mental and physical health. Rape by itself is an atrocity and due to its grave nature it is considered most serious crime all over the world. It is a form of sexual violence concerning contact with the body of women in the absence of her consent that violates her sexual autonomy. We can say that rape is an act of obliging women to have sexual intercourse against her will.

Rape has been regarded as a serious crime since the inception of Homo sapiens. Besides Islam, all other civilizations would also awarded strict punishment to the perpetrator of this crime. For instance, In Greece capital punishment was awarded to rapist under the law of Draco. In Roman civilization rapist was also subjected to wide range of capital punishment. In Judaism, both married women and married rapist were awarded punishment while only rapist was subjected to punishment if crime was committed in isolated place. ${ }^{1}$ In these civilizations women's honor, dignity and her sexual autonomy on her body would not matter because women were considered as a form of property of her father and husband. These ancient civilizations considered rape an offence committed by the victim as well as the rapist and both were liable to be punished. In Babylonia, for instance, a married woman who was raped had to be drowned in a river along with the rapist. In contrast to these civilizations, Islam stipulates that only perpetrator be punished rather than punishing both and Islam gives equal value to both men and women with regard to their honor and dignity. Majority of non-Muslim or western countries put the rape in the domain of sexual violence which includes acts such as flashing, sexual harassment, forcing someone to watch pornography, sexual bullying and other forms of non-consensual sexual act. In Islamic law every sexual act does not amount to rape. In Islam sexual act, which constitutes zina, can only be regarded as rape crime. Therefore, international law and Islamic law on rape are not parallel to each other.

In order to prevent rape, it is necessary to know what causes the rape. There is a strong link between rape and poverty. Poor women are more vulnerable to rape crime than an economically strong woman. Globalization

1 "should there be a virgin young women betrothed to a man, and a man find her in a town and lie with her, you should bring them both out to the gate of that town and stone them to death - the young women, because she did not crya out for help, and the man because he violated another man's wife, and you shall rout out the evil from you" (available at Deuteronomy 22:23-25, //https:www.blogs.timesofIsrael.com/the-torah-marry-yourrapist-law. 
is also a most cogent factor behind the commission of rape. Globalization has led to increase in the sexualization and commodification of women's body and the rises of internet have also led to increase access to pornography. Gender discrimination and women disempowerment may pave the way of rape culture. Poor criminal justice system is an effective tool in the hand of deep pocketed rapist to commit such crime with impunity. Indecent dressing of women may also become cause of rape. The modern way of dressing may provide the exposure of various erogenous zones on the body of women. Culture of silence also encourages the perpetrators to commit crime without any fear of blame.

\section{B. Islamic law on rape with special reference to coercion and punishment}

In Islamic law rape is considered serious sexual crime. It means forced nonconsensual sexual intercourse. Rape is literally translated in Arabic as $i g h t i s a b$.The word ightisab literally means usurpation, coercion, violation or rape. The classical jurists assumed rape as a sub-category of Zina. Therefore, they used legal meaning of rape that is Al Ikrah ala al-zina or Zina bi al$i k r a h^{2}$.

\section{Definition of Zina (Fornication)}

There is no clear definition given by the Muslim jurists regarding rape. In order to grasp the ingredients of rape, however, it is essential to investigate the jurist's definition of Zina (fornication) because Zina and rape are similar in most aspects. Zina comprises any illicit cohabitation between man and women who are not legally married to each other. In Islam lawful sexual relations are only those that occur within marriage or between slave girl and her master. The Quran says: "And those who protect their private parts except from their spouse or those whom their right hands possess, such are without blame. And whosoever desire beyond that, such are transgressor". ${ }^{3}$

The Holy Prophet (PBUH) is reported by Jabbar ibn Abdullah (RA) to have asked Maiz al Aslami (one of the companions of Prophet (PBUH), who confessed that he had committed zina): "Was the penetration like the stick entering the kohl jar or the rope entering the well?" Maiz said: "yes". The Holy Prophet (PBUH) asked another question, "do you know what Zina is". Maiz answered, "Yes", I know, and I committed an unlawful act which husband and

2 Ibn-Qudamah al-Maqdisi Muwaffaq Al Din Abu Muhammad, al-Mugni (Beirut: Dar al Fikr 1405 AH) 10:158.

3 Al-Quran, 23:5-7. 


\section{S. Shahid}

wife do lawfully"4. In this Hadith the Prophet (PBUH) established which sexual act outside of marriage and concubinage would amounts to Zina.

In Hanfi jurisprudence Zina is defined as: "unlawful vaginal intercourse with living women who is not one's own slave, not in the quasiownership of the man or not freely married or quasi married in an Islamic state" Maliki School defines Zina as: "vaginal or anal intercourse with women who is not under his ownership, willfully and with consent by both sides"6. The Shafi and Hanbali jurists define Zina as: "the unlawful and mutually consensual vaginal or anal intercourse between a man who is sane and who has reached the age of puberty and women who is not his legal spouse"7.

\section{What rape (Zina bil Jabr) is under an Islamic law?}

Jumhur (Majority of jurists) hold that committing Zina by using force or without the consent of women constitutes a rape. Elements of non-consent on the part of women and using force by the perpetrator morph Zina into rape. According to Hanfiates, illegal intercourse is considered rape when there is no consent and no deliberate action from the victim/women ${ }^{8}$. According to $\mathrm{Al}$ Shafi, forcing a women to commit Zina against her will constitute a rape ${ }^{9}$. AlShafi, further, asserts that it is unlawful to have sexual intercourse, both consensual or non-consensual, with captive women because Islam legalize sexual intercourse only with his wife and his concubine ${ }^{10}$.In Malki's views, any kind of unlawful sexual intercourse by usurpation and without the consent of women refers to rape ${ }^{11}$. In Malki's jurisprudence showing resistance on the part of women determine her consent or non-consent but Malikiates also clarify that conditions such as insanity, sleep or being

4 Imam Ahmed bin Hanbal, Musnad Ahmed bin Hanbal, Hadith no 21083 \& 22235. See also Muhammad Nasir al din al-Albani , Daif Abi Dawud, Hadith no 4428 (Beirut: AlMaktab al-Islami $1412 \mathrm{Ah}$ ).

5 Al-Kasani Ala Al Din Abu Al-Hassan Ali Ibn Sulaiman, Bada'I Al Sanai Fi Tartiba al Sharai (2 ${ }^{\text {nd }}$ edn, Beirut: Dar ul-Kitab Al-Arabi 1982) 7:33.

6 Malik Ibn Anas bin Malik bin abi Amir, Al Mudawwana Al-Kubra (Cairo:Marba'at alsa'ada,1905) 4:40.

$7 \quad$ Al-Suyuti Jalal al Din Abi Bakar, al-Ashbah wal-nazair (Beirut: Dar al Kitab al-Arabi 1987) 458. See also Mansur Ibne Younus Ibn Idris al Bahuti, Sharah Muntha al Iradat ( Madina: Al Maktaba al Salafia n.d ) 3:342.

8 Muhammad Amin Ibn Umar Ibn Abideen, Hashiat Rad al Mukhtar (Beirut: Dar Ul Fikr 1836) 4:30.

9 Muhammad Ibn Idris Al Shafi, Kitab al- Umm (Cairo: Dar al Shab 1321 AH) 3:230.

10 Sharah al Nawawi ,Sharh Sahi Muslim 1456(available at Abu Amina AIias,There ios no theology of rape in Islam,Faith in Allah,August 20,2015 https://abuaminaelias.com/no-theology-of-rape-in-isalm/ accessed on 8 Oct 2020.

11 Malik Ibn Anas (n 6) 4:401. 
underage of women prevents the victim to show resistance during forcible unlawful sexual intercourse ${ }^{12}$. According to Hanbali jurisprudence, denial of consent and showing of resistance during unlawful sexual intercourse on the part of the women constitutes a rape. In Hanbali jurisprudence, the threat of starvation or suffering the cold of winter is suffice to determine non consent ${ }^{13}$.

Consent of the women is considered as the most important element in rape. It can be understood from the above juristic definition of rape that two elements (a) act of unlawful sexual intercourse (b) non-consent of women must be present to constitute a rape. Non-consent and coercion may be used as inter-changeably. Non-consent/coercion of the women is considered as an important criterion that distinguishes rape from Zina. It is clear from the conversation between Holy Prophet (PBUH) and Maiz that full sexual intercourse must take place between man and women to constitute a Zina. Full sexual intercourse means that man has used his natural penis to penetrate the vagina of women no matter how little it penetrates, moreover it doesn't matter whether semen ejaculate or not. ${ }^{14}$ Ibn Nujaim of the Hanfiates asserts that even if the penis has been amputated, but there still remains a tiny part of the glan, the man would be convicted of Zina. ${ }^{15}$ It implies that, under Hanfiate jurisprudence, a man cannot be charged with rape offence unless he has used his natural sexual organ to penetrate the reproductive tract of women. Man. However jurists of Malkiates, Shafiate and Hanbliates school of law hold that, if a man has anal intercourse with women without her consent, the act will also constitute a rape. There is consensus among jurist that forcible penetration by hand or by any other object rather than genital of man does not constitute rape. In a report describing a decision by al-Hassan, a man had a slave girl. His wife feared that he would marry her, so she deflowered her with her finger, with the help of some other women holding her, then the case was taken to Hazrat Ali (RA), who commanded alHassan to judge between them. Al-Hassan said "I opine that she should be flogged the hadd for Qadaf of the other, and that she be fined the dower amount for the deflowering"16. It is necessary to constitute rape that women must be a living person. According to the definition of Hanfiates, a sexual act with dead women does not constitute a rape ${ }^{17}$. A man can only be charged with committing rape when he has forced sexual intercourse onto women to

\footnotetext{
12 Ibid.

13 Al Bahuti, kashf al Qina, (Beirut: Dar Ul-Fikr 1412 AH) 6:97.

14 Al-Kasani (n 5) 7:181.

15 Ibn-Nujaim, al Ashbah wa al Nazair 344.

16 Abd al Razzaq ibn Hammam al Himyari, Al Mussanaf (Beirut: Dar ul kitab al-ilmiya 2000) 7:330.

$17 \quad$ Al-Kasani (n 5) 7:33.
}

Indonesian Journal of Advocacy and Legal Services, Vol. 3 No. 1 (2021) 55 


\section{S. Shahid}

whom he is not legally married. Thus, all jurists unanimously agree that only non-consensual sexual intercourse that amounts to Zina can be termed as rape (zina bil jabr).

\section{Legal liability of compelled/coerced women}

There is a strong link between compulsion and non-consent. Compulsion (ilja) refers to a phenomenon when a woman is compelled, by force or without force, to submit for sexual intercourse. Compulsion may be defined in term of coercion and necessity. Women may be compelled to commit act by way of coercion or necessity. The source of coercion is from aggressor (such as person's threat of death, harm or imprisonment) while the source of necessity is from natural circumstances e.g. when women find herself alone in forest and desert. Coercion is considered as one of the most important element of rape that affects the criminal liability of a person. Sometime consent of women may be taken by coercion. Therefore, it is necessary to understand the nature of coercion. A person is said to be coerced when he/she acts contrary to his/her preference or will because of threat administered by another agent ${ }^{18}$. Muslim jurists are agreed that person is not held criminally liable for the act he/she commits under coercion. Their arguments are in fact in line with this saying of Holy prophet (PBUH): Allah has pardoned for me, my ummah; their mistakes, their forgetfulness and what they have done under duress. ${ }^{19}$ Coercion (duress) may be of Ikrah Mulji(compelling/perfect) as well as Ikrah naqis (Imperfect). All jurists agreed that coerced man is exempted from Hadd punishment of Zina only if coercion is compelling such as serious threat of death or losing his limb. However, as far as criminal liability of coerced women is concerned, Jurists held that imperfect coercion such as simple threat of minor injury to coerced women or her close relative is sufficient to exempt her from Hadd punishment. Al-Sarakhsi held that whether coercion is compelling or imperfect coerced women cannot be awarded the punishment of Hadd for Zina. ${ }^{20}$ Bazdawi, similarly, asserts that imperfect coercion such as imprisonment or slight beating also exempt women from legal punishment because it is sufficient to create doubt ${ }^{21}$. Abu Yousaf also exempts women from Hadd penalty in case she is coerced for sexual

18 Abi Sahl Abu Bakr al-Sarakhsi, al-Mabsut (Beirut: Dar ul_kutab al-ilmia 1997) 24:80.

19 Sunan ibn Majah, Hadith no 2043, https://abuminaelias.com/dailyhadithonline2012/4/10Allah-forgive-mistake-coercion, accessed on 8 Oct 2020.

$20 \quad$ Al-Sarakshi (n 18) 9:77.

21 Abd al Aziz ibn Ahmed Bukhari, kashf al Asrar an Usul Fakr al Islam al Bazdawi, Abdullah Muhammd Umar(ed), (1 ${ }^{\text {st }}$ ed, Beirut: Dar ul kutub al ilmiya, 1997) 4:556. 
intercourse, it does not matter whether threat is compelling or imperfect 22 . Ibn-Qudama states that "there should be no Hadd for the woman, who is forced to have sexual intercourse, according to the view of the majority of the jurists" ${ }^{23}$. In this way, all jurists agreed that a coerced woman will be considered as a victim of rape irrespective of the fact whether coercion was compelling or imperfect.

Necessity is a subset of compulsion. Sometime natural circumstances may force women to engage in survival sex in exchange of food, water or shelter in order to save her life or her child. Under Islamic law 'dire necessity renders the forbidden permissible'. ${ }^{24}$ Therefore, woman is also exempted from punishment if she claims that there was dire necessity or extreme urgency and no lawful alternate was available other than to submitting her for unlawful sexual intercourse in order to save her life. For instance, during the reign of Hazrat Omar (RA) a woman was brought before him and charged with Zina. She claimed that she was thirsty and asked shepherd for some water. The shepherd refused unless she agreed to have sexual intercourse with him. Hence, she was left with no option. Hazrat Omar (RA) after consulting with Hazrat Ali (RA) dropped case against her. It is because; in this situation the consent was not voluntarily but out of necessity to save her $\operatorname{life}^{25}$.

All these situations do not legalize the act of women but only exempt women from legal responsibility. The rationale behind this is that a woman is physically weak creature. She cannot avert physically superior aggressor. All jurists agreed that due to coercion women is not legally responsible for her unlawful sexual intercourse and there is possibility of doubt about her consent. Thus, in this situation if women claim rape she would not be asked to prove her case because her act does not harm any other person. Besides these circumstances, unlawful sexual intercourse is also considered rape when victim is mentally and physically incapable to give consent. There are situations where a claim that there was consent on the part of women cannot be accepted. Following circumstances are being described below which are similar to coercion.

The consent given by the women while in state of intoxications is void even though her intoxication is voluntarily. Unlawful copulation with a female who is intoxicated to the extent that she is unable to resist is classified as an act of rape because the victim does not realize what is happening to her.

22 Abu Yousaf, Kitab al-Khiraj, Niaz ahmed Okarwi(ed) (Maktaba Rehmania) 443.

23 Ibn Qudamah, al-Mugni (Cairo: Matba Al imam, 1964) 8:186.

24 Ibn-Nujaim, Al Isbhah wa al Nazair fi al fiqh al Hanafi (karachi:Qadimi Kutab Khana) 87.

25 Ibn Qudamah (n 23) 8:319. 


\section{S. Shahid}

Intoxication results in unconsciousness of person. Al-Juwayni says: "duties are imposed on the human subject when he/she has presence of mind such that he/she is able to understand the Divine address. If the agent is not in such state, it is inconceivable that he/she could intend to comply with the command before understanding it" 26 . Similarly sleeping women is also exempted from punishment. ${ }^{27}$ If women are given a sleeping pill, for instance, and resultantly she losses her conscious then only perpetrator would be liable for legal punishment. A women from Yemen was brought to Hazrat Umar (RA), having been accused of adultery. She said that she was sleeping when a man came and raped her. She woke up only after being captured in the man's grip. She was acquitted ${ }^{28}$. To Baqlani: "actions of agent or women in the state of intoxication or asleep are not morally significant because absence of capacity for rationality undermines the imposition of duty" ${ }^{29}$. Unlawful Sexual intercourse with incapacitated or insane women constitutes a rape because mentally impair women has no capacity to give consent. For instance, during the time of Hazrat Omar (RA) an insane woman was charged with adultery. She was acquitted on the base of following hadith: "Three people would not be accountable for their actions; a child until he has a nocturnal emission, a sleeping person until he wakes up and an insane person until he recovers ${ }^{30}$.

Muslim jurists agreed that unlawful sexual intercourse with a woman who has not reached the age of puberty constitutes a rape. The consent of women, while she has not attained the age of puberty is irrelevant. Hence, the act would be amounted to rape and the minor girl will be exempted from legal liability. Similarly, consent obtained by fraud also exempts women from punishment. Consent is considered invalid if a man pretends to be husband of women with whom he has sexual intercourse. In this situation the man will be charged for committing rape and the woman does not legally liable for her consent.

26 Al-Juwayni Dhia ul Din Abd al Malik Ibn Yusuf, al-Burhan Fi Usul ul-Fiqh, Abd alAzam al-Dib(ed) (1 ${ }^{\text {st }}$ edn, Qatar: jamia Qatar 1979) 1:55.

27 Abu Yousaf (n 22) 404.

28 Al-Bayhaqi Abu Bakar Ahmed Ibn Hussain Ibn Ali, Sunnan al-Kubra lil-Bayhaqi (Dara tul Marif, 1925) 8:236.

29 Baqillani Abu Bakar Muhammad Ibn al-Tayyib, al-Taqrib Wa al-Irshad al-Saghir, Abd al-Hamid ibn Ali Abu Zunyad(ed) (1 ${ }^{\text {st }}$ edn, Beirut: Muassasat al-Risalah 1993-1998) 1: 251-52.

30 Abu Daud Sulaiman Ibn al-Ashatal Sijistani, Sannun abi Dawood, Muhammad Muhyi al-din Abd al-Hamid(ed) (Cairo: Dar ul Fikr 1980) 4:558. 


\section{Moral and legal liability of coerced man}

Muslim jurists have considered the possibility of man being coerced into having sexual intercourse with women/victim. All jurists unanimously agreed that women are exempted from legal responsibility in case of compelling as well as imperfect coercion. They reasoned that she does not harm any person because of her passive role during such activity. However, such is not the case when man is coerced to commit rape. Thus legal responsibility for the coerced man is not the same as the women because of the active nature of man's role in rape. The Hanfiates attached the legal responsibility of coerced man according to the intensity of coercion. The Hanfiates attributes two opinions to Abu Hanifa regarding coerced rape. In the first opinion Abu Hanifa held that a man who is coerced to commit rape should be held liable for the punishment of Hadd. His rationale behind this opinion is that: "a man's erection is inconceivable without pleasure, pleasure is evidence of willingness. Erection does not occur in the presence of fear. And erection of man's organ cannot occur without desire (shahwa)" 31 . Later on, Abu Hanifa modified his opinion and held that if the coercer is not a ruler, then the coerced would be liable for Hadd ${ }^{32}$. However, it is not to say that Abu Hanifa considered the threat of non-ruler less compelling than the ruler because in case of non-ruler, Abu Hanifa believed, coerced may ask help from the ruler; whereas if coercer is ruler then coerced is left with no option to ask help against the ruler. ${ }^{33}$ According to Abu al-Hassan al karkhi , Abu Hanifa believed that if the ruler order someone to commit rape, then he has disqualified himself from the position of ruler. ${ }^{34}$ Under Islamic jurisprudence, it is only the head of state who can execute Hudood punishments. ${ }^{35}$ In this way coerced has committed a punishable offence when there is no head of state. ${ }^{36}$ Sarakhsi justified the second opinion of Abu Hanifa that "an erection is not evidence of absence of fear. An erection sometimes occur naturally without choice because of the strength of sexual desire the Allah implanted in men and sometime it occur by way of volition. Consider that someone asleep may have an erection, naturally without choosing it or intending it" 37 .

31 Al Jassas Abu Bakar Ahmed Ibn Ali, Sharh Mukhtasar al Tahawi Fi al-Fiqh al-Hanfi, Ismat ullah Inayat(ed) (1 $1^{\text {st }}$ edn, Beirut: Darul Bash aer-al Islamiyah lil Tiba a wa al Nashr wa al-Tawzi 2010) 8:45.

$32 \quad$ Al-Sarakhsi (n 18) 9:67.

33 Mawlana Aftab Ali, Fatah al Waqayah li hal Sharah al Waqayah (Kutab Khana Makki) $3: 82$.

34 Al-Jasas (n 31).

35 Abu Yousaf (n 22) 404.

36 Al-Jassa (n 31).

37 Al-Sarakhsi (n 18) 9:67. 


\section{S. Shahid}

Abu Hanifa's two disciples Abu Yousaf and Shybani held that if nonruler is capable of fulfilling his threat in the same way as the ruler then coerced is not liable for Hadd punishment ${ }^{38}$. Sarakhsi asserts that coercion does not affect the prohibition against rape. He says: "if the coerced performs the act of rape, he has committed an injustice. The prohibition against fornication is eternal. It admits no exception" 39 . According to Sarakhsi and Al-Jassas threat of imprisonment and beating do not amount to compelling coercion, however, he can be exempted from legal liability if coerced has no access to food and water and he has reached the starting point of death by starvation ${ }^{40}$. Bazdawi's view is also in line with Sarakshi. He writes: "fornication, similar to homicide and injury, are those acts that coercion can neither permit, nor excuse, because the evidence for excuse is fear of loss [of life or limb] and in this respect the coerced and the person whom the coerced would violate are equal. Coercion is legally and morally eliminated in cases dealing with the life of person whom the coerced would violate, because of [incommensurable] conflict [between the values of two person]" 41 . Jassas shared the first opinion of Abu Hanifa that coercion can never permit rape because the act harms the other people ${ }^{42}$. The Hanfiates made consensus that if the coercion is compelling (Ikrah Mulji) such as threat to one's life and limb, then he is not liable for Hadd punishment. However, Hanfiate jurists held that it is better for the coerced man to sacrifice his life rather than committing rape $^{43}$.

According to Hanbli school, even coerced is threaten with death, he is liable for Hadd penalty. Their argument is based on the fact that a man would commit fornication only when he had sexual desire and distension of male organ is not possible when he is in the strong grip of fear ${ }^{44}$. Like Hanfiates, the Malkiates also held that if coerced is threatened with compelling coercion (Ikrah Mutlaq), then he is not liable for Hadd penalty ${ }^{45}$. However Baqlani (Maliki Jurist) adopted a stringent position toward coerced. He held that coerced is still held morally responsible for it, even it is impossible for a

38 Al Sarakshi, Kitab al Mabsut, Abu Abd ala Muhammad Hasan Ismail al-Shafi(ed)

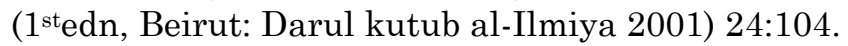

39 Ibid, 24:105.

$40 \quad$ Al-Jassas (n 31) 4:438.

41 Bazdawi and Bukhari (n 21) 4:562-63.

42 Abu Bakar Ahmed Al-Razi Al-Jassas, Ahkam al-Quran, Abd al Salam Muhammad Ali Shahin(ed) (Beirut: Darul Kutub al-ilmiyya, n.d) 3:251.

43 Al-Sarakhsi, (n 18) 24:105.

44 Gulam Rasool Saeedi, Tibiyyan ul Quran ( Roomi Publishers and Printers Lahore 2013) 8:46. See also Wahbah al-Zuhayli, Al Fiqh Al Islami Wa Adallatuhu (2 $2^{\text {nd }}$ edn, Damascus: Dar Al Fakr 1985) 5:401.

45 Ibid 8:46. See also ibid 5: 402.

60 Indonesian Journal of Advocacy and Legal Services, Vol. 3 No. 1 (2021) 
coerced to refrain from it. Baqillani asserts that "it is possible for Allah to impose on us the duty to omit every action we are coerced to perform, as coerced remain a moral rational during the course of coercion, therefore he is subjected to moral and legal responsibility" 46 . Shafiates hold that a person who is coerced to commit rape is not liable for punishment because it creates doubt about the intention of coerced47. According to them coercion does create doubt about the coerced liability, Therefore, he should be exempted from punishment. Abd al-Jabbar (a follower of Shafi School) notes that according to Abu Hashim, the compelled is one who, when impelled to two harms prefer the lesser over the greater ${ }^{48}$. To Abd al-Jabbar if the harm is far-off, timewise, or one of them is far-off, then the compulsion no doubt ceases49. Many jurists rejected the two harm theory because it cannot be applied equally in all situations without taking into account of the physical strength of the coerced. As, Bazdawi (Hanfiate Jurist) asserts: "there is no fathom to weigh the harm that would be suffered by the coerced against the harm that would be suffered by the victim from the act of coerced" 50 .He further added : "there is another harm in the case of rape .Rape causes pregnancy, and the pregnancy causes the ruination of the legal basis for attribution to the biological father". ${ }^{51}$

\section{Abortions of raped women}

Rape may result in pregnancy of victim. A rape victim is presumed innocent but Islam doesn't grant her absolute right to abort. In general, all jurists agreed that unnecessary abortion is sin and amounts to murder. They based their argument on following verse of Holy Quran: "And do not kill the soul which Allah has forbidden, except by right". 52

There is no explicit reference to abortion in Holy Quran and Sunnah. The Quran refers to the multiple stages of development of human embryo. ${ }^{53} \mathrm{At}$

46 Baqillani (n 29) 1:251.

47 Gulam Rasool (n 44). See also Wahbah al-Zuhayli (n 44) 5:401.

48 Abd al-Jabbar Ibn Ahmed Ibn Abd Al-Jabbar Al-Hamadani (935-1025 AD) a Mutazilite Theologian and follower of Shafi school, Al-Mugni Fi Abwab Al-Tawhid Wa Al Adl. edited by Taha Hussain and Ibrahim Madkur(ed) (Cairo: Wizarat al-Thaqfa wa alIrshad al-Qawmi, Al Idara al Amah lil Thaqafia 1960-9) 11:394.

49 Ibid.

50 Bazdawi and Bukhari (n 21) 4:562.

51 Ibid 4:562.

52 Al-Quran, 17:33.

53 "And certainly did We create man from an extract of clay. Then we placed him as a sperm-drop in a firm lodging. Then We made the sperm-drop into a clinging clot, and We made [from] the lump, bones, and We covered the bones with flesh; then We developed him tnto another creation.so blessed is Allah,the best of creators" (Al-Quran 23:12-14). 


\section{S. Shahid}

the end of third phase (40 days in each phase) of embryonic development the soul enters the body as hadith narrates:

"Verily the creation of each one of you is brought together in his mother's womb for forty days in the form of life germ, then he becomes a clot of congealed blood for a similar period, then he becomes a lump for similar period; then the angel is sent to breathe into him the soul54.

Based on above Quranic verse and hadith most jurists hold view that foetus has human value after 120 days of pregnancy. They argue that before ensoulment foetus is not a person. Therefore, under the flag of this hadith the Hanfiates permit abortion within 120 days of the inception of pregnancy but they also maintain that abortion must not be without reason55. Al-Bahuti (Hanbli jurist) also states that abortion is permitted as long as soul has not breathed in56. Similarly, Al-Ramli (Shafi jurist) hold that abortion is permitted within 120 days of inception as long as foetus has not turned into human shape.57 These jurists grant permission of abortion on the ground of followhbing hadith:

"There should be neither harming nor reciprocate harm in Islam" 58.

However, Most of the Malikites prohibit abortion absolutely on the ground that foetus has potential to become human being. Ibn Juzayy asserts that after inception of pregnancy there should not be interruption59. Al-Dardi also prohibits the dislodging of semen even before completion of 40 days60. However, minority of Malikite jurists permit abortion within 40 days of inception of pregnancy.

Aborting the pregnancy resulted from rape is considered concrete reason but it is necessary that abortion must take place within 120 days of inception of pregnancy/before the period of breathing the soul according to most of Hanfiates, Shafiates and Hanbliates. In 1998, the Egyptian Grand Shiekh of Al Azhar, Muhammad Syed Tantawi, issued a fatwa that unmarried woman who had been raped should have access to abortion. In same year, Islamic supreme council of Algeria also allowed abortion in case of rape. However, majority of jurists strictly prohibit abortion after 120 days

54 Al Bukhari Muhammad Ibn Ismail, Al Jamia al Sahih, Hadith no 6594 (Cairo: AlMaktaba al-Salafia, 1400AH)

55 Ibn Abidin, Minhat al Khaliq (Beirut: Darul Kitab al-Ilmiya 1997) 3:215.

56 Al-Bahuti, Sharh Muntaha Al-Iradat (Madina: al-Maktaba al-Salafia n.d) 1:115.

57 Al-Ramli, Nihayat al-Muhtaj (Beirut: Dar ul Kutab al Ilmia 1993) 8:442.

58 Ibn Majah Abu Abdullah Muhammad Ibn Yazid Ibn Majah, Sunnan ibn Majah (Beirut: Darul Kutub al-ilmiyya, 1998) 2:784.

59 Ibn Juzayy abu al-Qasim Muhammad ibn Ahmed al-Kalbi, Al Qawanain Al Fiqhiyya, Muhammad Amin al-Dinawwi(ed) (Beirut: Darul Kutub al-ilmiyya, 1998) 141.

60 Al Dardi Abu Al Barkat Ahmed ibn Muhammad, Sharh Mukhtasar khalil (Cairo: Dar Al-Maarif 1986) 2:267. 
of inception irrespective of the fact that a woman was raped, except saving the life of the mother.

\section{Marital Rape}

The term Marital Rape is commonly used by the feminists who refer it non-consensual intercourse within marriage. This term does not exist in the works of classical jurists and it has been exported from the west. According to Islamic law rape is adultery by force, but if the woman is his wife, it cannot be termed as rape. Islam does not recognize women as a property of man but describes man and his wife as (LIBAS) garment for each other. The marriage between man and women is a contract that legalize their cohabitation after paying her dower but if this cohabitation take place without the consent of wife it does not constitute rape. Marital rape does not exist in Islam but it does not mean that a man has an absolute sexual right over his wife's body whenever he wants.

Islamic scholar ,Dr Wahbah uz-Zuhaily says that marriage is the legalization of enjoyment with a women in having intercourse, kissing and other, if that women is not the forbidden women due to blood relation, breastfeeding or marital relation61.

Islam urges both parties to be always welcoming to meet the other party's sexual demand and need. In Islam to meet the sexual needs of each other is praise worthy act. Refusal on the part of women is deemed a sinful act. The Holy Prophet (PBUH) says that even when they are riding on the back of camel, when the husband asks her, she must give62.

According to Islamic jurisprudence, sexual intercourse is both right and duty of husband and wife. Maliki School believes that sexual intercourse is compulsory between husband and his wife if there would be no excuse63. Shafi says that sexual intercourse is spouse's right64. According to Hanbli jurists husband and wife should do love making once in every four month if there would be no excuse65. Similarly Ibn Qudama opines that a man should spend one night in 4 month with his wife66. Ibn Taymiyah says that it is obligatory for the husband to have intercourse with his wife as much as it is

61 Wahbah uz- Z| uhayli, Al-Fiqh al Islami Wa Adilataha, (4 ${ }^{\text {th }}$ edn, Damascus: Darul Fikr 1997) 9:6513.

62 Al-Baihaqi, Al-Sunan al-Kubra, Hadith no 14714 ( $3^{\text {rd }}$ edn, Beirut: Daral-Kitab al-Ilmia 2003) $7: 478$.

63 Ibn Juzzay (n 59) 350.

64 Sayyid Sabiq, Fiqh as sunnah (3 $3^{\text {rd }}$ edn, Beirut: Darul Kutub al-Arabi 1997) 2:188.

65 Al-Bahuti, kashf ul Qana (Beirut: Darul Kutub al-ilmiyyah, 1983) 5:192.

66 Ibn Qudamah (n 2) 7:28. See also ibid 3:144. 


\section{S. Shahid}

needed to satisfy her.67 Thus, there is consensus among jurist that sexual intercourse is a right as well as duty of husband and wife and they should not refuse without reason.

However in the following situations, Islam commands both parties to refrain from cohabitation. In the following situation Islam gives women absolute right to refuse, even husband request it. First, during menstruation period68. Second, during the day time of Ranadan69. Third, when she is performing Umrah or pilgrimage. Fourth, when husband put away his wife by likening of her backs to the backs of his mother(Zihar)70. Fifth, when foetus in her womb is in advance stage. Sixth, during her parturition period. Seventh, when husband is suffering from contagious or sexually transmitted disease. Eighth, when wife is mentally or physically unfit.

Except these conditions wife is commanded not to refuse. Some Religious scholar use the term "Tamkin Khas" which means that wife should submit herself to her husband whenever he desire if there would be no excuse 71. This means if women refuse to have sex with her husband, he does not have to pay his wife maintenance, clothing and lodging. Some scholar gives husband an unlimited right over his wife's body. They based their argument on the following verse of the Holy Quran and saying of Holy Prophet(PBUH)

The Holy Quran reads: "Women are your field; go' then, into your field as you please"72.

Similarly, the holy prophet (PBUH) in his final sermon which was delivered during the hajj of year 632C.E said "if (they) abide by your rights then to them belongs the right to be fed and clothes in kindness"73.

However, the Holy Prophet (PBUH) interpreted above-mentioned verse that one is free to have sexual intercourse with his wife, in any position, as long as it is vaginal.74 This interpretation shows that husband has no absolute right over the body of her wife. It is also saying of Holy Prophet (PBUH) "no one among you should have sex with his wife like animal".75

67 Ibn Taymiyyah, Al Ikhtiyarat Al Fiqqiyyah Min Fattawa Ibn Taymiyyah, ( available at https://www.quoro.com/what-islams-stance-on-marital-rape.

$68 \quad$ Al-Quran 2:222.

69 Al-Quran 2:187.

70 Al-Quran 58:1-4.

71 International Approaches to Rape, Breaking the Silience :Rape law in Iran and Controlling and Women's Sexuality (2011)Briston University Press 137.

72 Al-Quran, 2:223.

73 Abu Daud Sulaiman bin Al Ashath Bin Ishaq al Sajistani, Sunan abu Daud, Hadith no 2177, Vol 3 (Damascus: Dar ar Risalah al-Alimah 2009)

74 Abu Hamid Imam Muhammad Gazali, Ahya ul Uloom, Faiz Ahmed Awaisi(ed) (Lahore:shabbier Brothers) 2:95.

75 Tahzib ul Ihya 3:110. See also Imam Gazali (n 74) 2:94

64 Indonesian Journal of Advocacy and Legal Services, Vol. 3 No. 1 (2021) 
The Holy Prophet (PBUH) is reported by Abu Hurairah(RA) to have said: "if a man invites his wife to sleep with him and she refuse to come to him, then the angels send their curse on her till morning"76. This hadith shows that even when women refuse without any reason, the husband should not use violence.

If husband uses violence upon his wife to having sex with him, he cannot be charged with rape. In Islamic law a husband can only be charged with committing rape when he forces sexual intercourse upon unlawful women. It is suggested that if women refuse without any reason then man should convince her mind voluntarily by setting a romantic atmosphere and by being affectionate rather than forcing her or falling upon her like an animal.

\section{Punishment of rapist in Islam \\ a. Hadd of zina}

All jurists agree that in non-consensual sex, perpetrator is only liable for punishment whereas victim is exempted from criminal liability. However, as Quran does not directly deal with rape, hence, jurists disagree over the issue of the punishment of rape. Classical jurists did not consider rape and Zina as separate crimes rather rape was considered as the subset of Zina. Majority of classical jurists agree with inflicting the Hadd penalty of Zina to a convicted rapist. Those jurists who considered rape as a subset of Zina are of opinion that punishment for the offence of rape is stoning to death for the married and 100 lashes for unmarried.77 If fornicator is slave then he/she will receive half the punishment of free person that is 50 lashes, irrespective of the fact that whether he/she is married or not78. However, there disagreement exists over issue whether the punishment of banishment and financial compensation may be awarded to rapist besides awarding him the Hadd of Zina( it will be discussed in next section). Similarly, there is consensus among majority of classical jurists that non-married perpetrator is exiled for one year besides awarding him punishment of 100 lashes;79 however, they are disagreed over the issue whether or not married person would be awarded 100 lashes before awarding him the punishment of stoning to death (rajm). Holy Prophet(PBUH) is reported by Salma bin Muhabbiq to have said :"there is 100 lashes and one year of exilement for non-married man/women and if married person commit such act he/she will awarded 100

76 al Bukhari muhammad bin Ismail, Al Jami al Sahi, Hadith no 3237.

77 Al-Bukhari Muhammad bin Ismail, Al Jami al Sahi, Hadith no 6815, 5270 and 2314.

78 Ahmed bin Hanbal, Musnad Ahmed bin Hanbal, Hadith no 820.

79 Al-Bukhari, Al Jami al Sahi, Hadith no 2314. See also Ahmed bin Hanbal, Musnad Ahmed bin Hanbal, Hadith no 22114. 


\section{S. Shahid}

lashes before stoning him/her to death(Rajm)80. For this reason, Hanbli jurists maintained that married person must be awarded 100 lashes before stoning him to death81. Whereas, Imam Malik And Imam Shafi held that Hadd punishment of Zina for married person is only stoning to death(Rajm)82. However, all traditional jurists are on same page regarding the Rajm of married person (Muhsan) and they based their opinion on the following hadith of Holy Prophet (PBUH) narrated by ibn Masud: "a Muslim should not be killed except for three offences: adultery committed by married person, a murderer and apostasy 83

Those jurist who apply Hadd of Zina for convicted rapist based their argument on the practice of Prophet (PBUH) and Caliphates. Their argument is based on the fact that rape involves the right of Allah and the right of an individual, as the right of Allah takes precedence, therefore, convicted rapist will receive Hadd of Zina.

Abu Alqama reported: A woman went out to pray during the time of the Prophet (PBUH) and she was met by a man who attacked her and raped her. That man was brought before the Holy Prophet (PBUH). She said, "This man has molested me!" The Holy Prophet (PBUH) condemned him to death whereas the woman was not awarded any punishment84. Similarly, during the reign of Hazrat Abu Bakar(RA) a man was invited as a guest of the family of a household, and then he forced himself upon a woman among them. It was referred to Abu Bakar(RA), so he flogged him and expelled him, and he did not flog the woman85. Umar ibn al-Khattab (RA) was presented with a servant girl who was raped by slave man. Hazrat Umar(RA) flogged the man and he did not flog the woman86.

All jurists have consensus on this issue that if man forcefully

commits Zina with a slave girl who is not in his ownership he will receive Hadd of Zina. If aggressor is, however, a slave man he will receive Hadd of Zina which is 50 lashes regardless of his marital status.87 Similarly, if a man

80 Ahmed bin Hanbal, Musnad Ahmed bin Hanbal, Hadith no 16005.

81 Ahmed bin Hanbal, Musnad Imam Ahmed bin Hanbal, Abbas Anjum and other(eds) (Ansaar Al Sunnat Publicationers n.d) 481.

82 Ibid.

83 Al Bukhari Muhammad ibn Ismail, Al Jami al Sahi, Hadith no 6827 (Cairo: al-Maktaba al-Salafia, 1400AH).

84 Ahmed bin Hanbal, Musnad Ahmed bin Hanbal, Hadith No 19078. Sunnan al-Tarmidi, Hadith no 1454.

85 Mussanaf ibn abi shybah, Hadith no 29013 available at $</ /$ https:www.abuaminaelias.com/there-is-no-theology-of-rape-in-islam>accessed on 8 Oct 2020.

86 Imam Muhammad Hassan Shaybani, Sharh Muwatta Imam Muhammad, Muhammad Ali(ed) (Freed Book stall Lahore) 2:659.

87 Ahmed bin Hanbal, Musnad Ahmed bin Hanbal, Hadith 1142.

66 Indonesian Journal of Advocacy and Legal Services, Vol. 3 No. 1 (2021) 
forcefully acquired a slave girl and then has intercourse with her thereafter, and he is not ignorant, the slave girl is taken away from him, he is fined, and he is punished for adultery 88 .

Majority of classical jurists held if rapist rape the free women, slave women, captive women or non-Muslim women (Dimmi), he would be awarded Hadd of Zina whereas victim women is exempted from Hadd punishment.

\section{b. Hadd of Hirabah}

According to some modern Muslim jurists rape should be classified as Hirabah crime because unlike Hadd of Zina it does not require strict evidentiary procedure. It is consensus among the jurists that the law of Hirabah is extracted from the verse of Quran that reads:

"Indeed, the penalty for those who wage war against Allah and his Messenger, and strive upon earth [to cause] corruption is none but that they be killed or crucified or that hands and feet be cut off from opposite sides or that they be exiled from the land" 89

However Muslim jurists disagree on whom this verse was revealed. According to Malik and Shafi this verse was revealed on group of Muslim90. According to Ibn-Umar this verse was revealed for apostates91. According to some jurists this verse was dedicated to Uraniyyin who killed a shepherd and took away his camel. Anas bin Malik is reported as saying:

Some people from Urayna (or Ukil) tribe came to Madinah after accepting Islam they acquired an illness due to the climate, for which the Arabs used to drink milk and urine of camel as medicine.The Holy Prophet (PBUH) allowed them to go to the herds of camels for their medicine. After recovering from their illness, they killed the shepherd and drove away the camels. The Prophet (PBUH) ordered their hands and feet cut off, their eyes branded with heated pieces of iron, and they were left in the desert92 .

However, according to some jurist after this incident Allah (SWT) prescribed the punishment for those who wage war against Allah and His Messenger and forbidden the Holy Prophet (PBUH) to punish the perpetrator of Hirabah crime other than these punishments. Modern jurist's line of reasoning behind the incorporation of rape in Hirabah crime is to avoid strict evidentiary procedure to prove Zina. Not only modern jurists but few traditional jurists have also considered rape as a Hirabah crime. Ibn Arabi

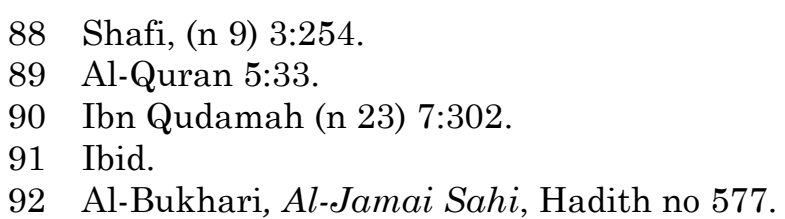




\section{S. Shahid}

relates a story in which a group was attacked and women in their party raped. When this incident was brought to trial, some people claimed that this case was not Hirabah, because Hirabah can only involve property. In responding to this argument, ibn Arabi asked "was not rape worse than robbery? Ibn Arabi justified that "people will not usually fight to protect their property if their lives are in danger but fight in same situation if their wives or daughters are going to be raped or their modesty is being outrages"93. Ibn Hazm defines Hirabah as "one who puts people in fear on the road, whether or not with the weapon, at night or day, in urban area or in open space, in the place of a caliph or a mosque, with or without accomplices, in the desert or in the village, in a large or small city, with one or more people making fear that they will be killed, or have money taken, or be raped, whether the attackers are one or many.94

Modern scholar Asifa Qureshi says: "Sharia shows that the crime of rape is classified not as a sub-category of Zina, but rather as a separate crime of violence under Hirabah. This classification is logical because the "taking" is of the victim's property (the rape victim's sexual autonomy) by force. It is logical then, that the Islamic law would classify the taking by force of some one's right to control the sexual activity of one's body as a form of Hirabah. Moreover, Hirabah does not require four witnesses to prove the offence. Circumstantial evidence and expert testimony, then, presumably form the evidence used to prosecute such crime. In addition to using eye witness testimony, medical data and expert testimony, a modern Hirabah prosecution of rape would likely take advantage of modern technological advances such as forensic and DNA testing"95.

Jurists who assert that rape is a Hirabah crime base their argument on the opinion of Malik. Hirabah is defined by Malik as" the act of terrorizing people for the purpose of robbery or other purposes96. Ismail bin Muhammad also share the opinion of Malik that Hirabah is the act of terrorizing the people who terrorize in Dar ul Islam (abode of Islam), either by killing people, robbery, rape or destroying their farms 97.

However, according to Abu Hanifa, Shafi and Ahmed, the crime would not be considered as Hirabah as long as offender does not use any weapon.

93 Ibn al-Arabi Muhammad ibn Ahmed, Ahkam al-Quran (Cairo: Isa al-Hlabi 1958) 2:247.

94 Ibn Hazm Abu Muhammad Ali ibn Ahmed, Kitab al-Muhalla bil Athar (Beierut: Darul Kutub al-Ilmiyya 1988) 11:308.

95 Asifa qureshi ,'Her Honour:an Islamic critique of the rape provisions in Pakistan's ordinance on Zina (kuala lampur : Islamic book trus 2002) 19.

96 Al Ramli Shamas al Din Muhammad, Nihayat al-Muhtaj ila Sharah al Minhaj (Cairo: Matba Mustafa Al Halabi 1938) 8:2.

97 Ismail Muhammad Bakar, Al Fiqh al Wadih Bayan al Kitab Wa al Sunnah (Cairo: Dar Ul Manar 1990) 2:257. 
Similarly, Malkiates and Ibn Hazn are of opinion that in order to put rape in the domain of Hirabah it is necessary that the perpetrator must have used weapon or force against the victim98. Hence, it seems from the opinions of these jurists that where weapon is used against victim in pursuance of rape then perpetrator may be awarded Hadd punishment of Hirabah. In this way, unlawful sexual intercourse with underage women, sexual intercourse by fraud or sexual intercourse with women who is in a deep sleep will not be dealt under Hirabah offence.

\section{c. Ta'zir}

The punishment for the Hudood offences is fixed by the Quran or hadith. Qisas allows equal retaliation in cases of intentional bodily harm, while Tazir refers to punishments applied to the other offences for which no punishment is specified in Quran or hadith. Tazir refers to the punishment for offences at the discretion of judge or ruler of the state. Some modern jurists assert that, the Quran does not directly deal with rape; therefore they consider rape as Tazir offence.

\section{Juridical Issues emanating from forced sexual intercourse}

1. Issue of circumstantial evidence when unmarried pregnant women claim rape

There is disagreement among jurists regarding the issue of unmarried pregnant women who claim rape. According to Imam Abu Hanifa pregnancy of unmarried women may be regarded as a proof of Zina. However, he also states that an unmarried pregnant woman who claims that she was forced to have sex is not liable for Hadd punishment, and she will not be required to prove coercion or identify her attacker99. His argument is based on the practice of Hazrat Umar(RA). A pregnant unmarried woman was charged with Zina. She claimed that she was raped. Hazrat Umar (RA) dropped charge against her because of doubt and predicated his reason on the saying of Holy Prophet (PBUH): "dismisses the Hadd if there is an element of doubt"100.

Whereas, Imam Malik states that pregnancy of unmarried women is sufficient to proof Zina . However, unlike the opinion of Abu Hanifa ,Imam Malik asserts:"a women who is found to be pregnant and has no husband and

98 Ibn Hazn, al-Muhallah (Beirut: Darul kutub al Ilmia 1988) 11:308.

99 Ibn Qudamah, al-Mugni ala Mukhtassar al-Kharaqi (Cairo: Darul Kutb al-Ilmiyyah 1994) 8:129.

100 Sunan Ibn Majah, Hadith no 2545. 


\section{S. Shahid}

she says that she was forced to have sex , is not to be accepted and the Hadd will be inflicted on her unless she comes with bleeding or injury, or give evidence of calling for help from someone who saw her in that state. If she does not produce such evidence, her claim that she was raped will not be accepted and she will be charged with Hadd of Zina."101. Malik based his opinion on the position of Hazrat Umar(RA). Hazrat Abdullah bin Abbas (RA) narrates the saying of Hazrat Umar (RA) that a fornicator who is legally married is liable for the punishment of stoning to death (Hadd) when proof is established or if there is pregnancy or confession 102.

Both jurists agreed that circumstantial evidence such as pregnancy of unmarried women is an admissible proof to convict her of Hadd of Zina as long as she does not claim rape(under Hanfi jurisprudence) or does not produce evidence of being raped(under Malki jurisprudence). They rely on the statement of Hazrat Ali(RA):"O People! Actually there are two types of adultery: Hidden adultery and apparent adultery. Hidden adultery must be proved by eyewitnesses. Apparent adultery is when pregnancy is obvious".103 However, both are agreed that in such situation perpetrator cannot be awarded Hadd of Zina unless four Muslim male eye witnesses give testimony against the perpetrator. It means that circumstantial evidence such as DNA, CCTV and other modern technologies can be used to exempt unmarried pregnant women from Hadd punishment of Zina if she claims of rape, but not to convict rapist for Hadd of Zina. Some modern scholars hold that opinion of Imam Malik regarding unmarried pregnant women does not take into account the modern medical advancements such as artificial insemination and it unfairly places the burden of proof upon women 104. It is, however, unreasonable for unmarried pregnant women to conceal her pregnancy till the pregnancy is made public. Pregnant women can notice her pregnancy in $2^{\text {nd }}$ or $3^{\text {rd }}$ week following the incident. Majority of jurists held that women are permitted to abortion within 120 days of inception of pregnancy. Similarly, Malkiates also permits women to abort within 40 days of inception. Furthermore, pregnancy remains a private matter unless three months have elapsed. Therefore, as Islam permits her to abort within 120 days, unmarried pregnant women cannot be justified to claim rape after making the pregnancy public.

101 Imam Malik bin Anas, Muwatta, Allama Abdul Hakeem Akhtar (ed) (Fareed Book Stall Lahore) 720.

102 Ibid. See also Al-Bukhari, Jami al-Sahih, Hadith no 2462.

103 Ibn-Qudama (n 99) 10:193.

104 Asifa Qureshi , Her Honour: An Islamic Critique of the Rape Provisions in Pakistan's Ordinance on Zina (1999) 38(3) Islamic Studies. 
It is suggested, in case of rape both the right of Allah (SWT) and the right of individual are violated, hence, for the realization of the right of individual circumstantial evidence can be used to convict the rapist under Syasah/Tazir offence but not under Hudood offence. However, as Hadd of Zina falls in the domain of 'Right of Allah' therefore rapist cannot be awarded Hadd of Zina unless four Muslim male eyewitnesses give testimony against him. Similarly, In case of voluntarily fornication only the right of Allah is violated, therefore, it can only be proved with the testimony of four Muslim male eye witnesses. Unless fornication is committed in front of four Muslim male people, fornication remains a matter between Allah (SWT) and sinners. Therefore, neither circumstantial evidence nor less than four witness can prove the Zina whether consensual or non-consensual .However, when unmarried pregnant women makes her pregnancy public, she violates the right of Allah.105 Therefore, for the realization of the 'Right of Allah' circumstantial evidence such as pregnancy can convict her for the Hadd of Zina 106 unless she claims of being raped or proves that she was raped under Hanfi and Malki jurisprudence respectively. Undoubtedly, circumstantial evidence such as pregnancy of unmarried women cannot convict her of Hadd of Zina in case she claims of rape, if Hanfi jurisprudence is applied. However, making pregnancy public by unmarried women also falls in the domain of 'Right of community'. Therefore, for the realization of right of community/public the state has a right to convict her under Syasah/Tazir offence. In this way, the state has also the right to pardon her after taking into account some factors such as mental capacity of unmarried pregnant women, geographic disadvantage, confinement or physical disability.

\section{Forced sexual intercourse with pre-pubertal child girl or insane women}

There is consensus among all classical jurists that a man who commits sexual intercourse with minor girl (who has not attained the age of puberty) or insane women is liable for Hadd punishment of Zina107. However there is disagreement among classical jurists regarding the issue of child girl who is pre-pubertal or is not yet sexually attractive. Majority of traditional jurists held that if child girl is too minor that she is not yet sexually attractive then

105 It is clear from the statement of Hazrat Umar (RA)and Hazrat Ali (RA) that pregnancy of unmarried women is also a mood of evidence in case of Hadd of Zina. See above footnotes 102 and 103.

106 Ibid.

107 Ala al-Din al-Kasani, Badai al-Sanai Fi Tartib al-Sharia, Dr Mehmood Ul Hassan(ed) (Hatif Art Press Lahore, 1997) 7:102. 


\section{S. Shahid}

that sexual intercourse does not amount to Zina, hence, perpetrator is not liable for Hadd of Zina. According to Abu Hanifa sexual intercourse with a minor girl who is too minor does not constitute Zina and the perpetrator is liable for Tazir punishment108.

Rape of child girl may cause internal laceration and bleeding, in severe cases, damage to the internal organ may occur which may cause death 109. Penile penetration may be used as a tool of death in case of child girl. According to Abu Hanifa it does not constitute to Zina but worse than Zina. Abu Hanifa's opinion is in line with common reason that rape of child girl is only committed by habitual offender, therefore, death punishment as Tazir or Syasah appears more appropriate punishment than awarding the nonmarried offender mere 100 lashes.

\section{Women forces minor, insane or unlawful coerced man to have sexual intercourse}

There is disagreement among jurists regarding the issue of women who forces an unlawful man to have a sex with her. Jurists also disagree over issue of punishment when women voluntarily commit sexual intercourse with insane or minor. Abu Hanifa and Imam Muhammad opine that voluntarily illicit sexual intercourse of women with minor or Insane does not amount to Zina hence not liable for Hadd punishment of Zina 110. As far as issue regarding the voluntarily sexual intercourse of women with unlawful coerced man is concerned, Iman Muhammad unlike the opinion of Abu Hanifa exempts her from the Hadd punishment of Zina111. It is because, to Imam Muhammad, the exemption of Hadd punishment to coerced man also exempts women from Hadd punishment irrespective of the fact that women commit such illicit act voluntarily112. Whereas, Imam Shafi, Imam Malik and Iman Hanbal provided that a women would be punished for the Hadd of Zina if she forces insane ,minor or adult coerced man to commit sexual intercourse with her113.

\section{Punishment of Non-Muslim rapist}

108 Al-Sarakhsi (n 18) 9:86-87.

109 Rape and the Girl Child (2015) 14(1) IOSR Journal of Dental and Medical Sciences.

110 Al-Kasani (n 107) 7:102.

111 Ibid. See also Imam Muhammad Hassan Shaybani, Muwatta, Allama Muhammad Ali(ed), (Roomi Publishers and Printer Lahore 2005) 2:607.

112 Al-Kasani (n 107) 7:102.

113 Burhan al-Din al-Farghani al-Marghinani, (al-Hidaya)Ahsan ul Hidaya, Mufti Abdul Haleem Qasmi(ed) ( little Star Printers Lahore 2004) 6:245. 
Due to globalization and prevalent human rights conventions, Muslim states have to deal with the issue of non-Muslim rapist with extra cautious. There is also wide range of dispute among classical jurists regarding issue of non-Muslim fornicator who commit such act with Muslim or non-Muslim within Muslim state. In order to determine the legal jurisdiction of Muslim state, classical Muslim jurists categorized the world into Dar ul Islam(domain of Islam) and Dar ul Harb/kufr (domain of non-Muslim). Similarly, nonMuslims in Muslim state are categorized into dimmi (permanent resident of Muslim state) and non-dimmi/Harbi (temporary resident of Muslim state). The former are those who are nationals of the Muslim state while the latter consist of foreign non-Muslim investors, tourists, ambassadors and students. Abu Hanifa maintained that Muslim as well as dimmi is liable for Hadd punishment of Zina within Muslim state114. Similarly, Abu Yousaf and Imam Muhammad also shared the opinion of Abu Hanifa115. Whereas, Imam Shafi, Malik and Imam Hanbal held that non-Muslim, whether be dimmi or harbi, cannot be awarded Hadd punishment of Zina rather the perpetrator will be dealt under Tazir offence116. Imam Malik further maintained that if non-Muslim man uses force against Muslim women for sexual intercourse then he would be liable for death punishment as Tazir.117

According to international law, rapist ambassador is immune from the punishment of receiving state but receiving state can ask him to left the country by declaring him PERSONA NON GRATA. Foreign direct investment and tourism is an economic asset of the country. As, FDI and tourism has a major contribution in the country's GDP, therefore, awarding Hadd punishment to ambassadors, foreign investors and tourist may result in deindustrialization and diplomatic isolation of the country in global arena. As far as Hadd punishment of foreign non-Muslim is concerned, like Malki, Shafi and Hanbli school ,Abu Hanifa and Imam Mohammad also exempts temporary non-Muslim foreigner(such as, investor, tourist, ambassador) from Hadd punishment of Zina 118. In this way, awarding Tazir punishment to foreign non-Muslim rapist is, undoubtedly, in line with the opinion of all classical jurists except Abu Yousaf . Moreover, it will deter the foreign nonMuslim tourists, students and investors to commit rape as well as it will serve the national interests .However, non-Muslim rapist who is permanent resident of Muslim state may be awarded Hadd punishment of Zina.

114 Al-Kisani (n 107) 7:104. See also Allama Gulam Rasool Saeedi (n 44) 8:46.

115 Ibid 7:104. See also Marginani, (n 113) 6:244.

116 Allama Gulam Rasool Saeedi, (n 44) 8:48.

117 Ibid.

118 Al-Kasani ( n 107) 7:104. 


\section{S. Shahid}

\section{Issue of incest rape}

In the last few years occurrence of incest rape is being exposed by the police and media. Muslim jurists prescribe strict punishment to a person who commits sexual intercourse with the women of prohibited degree because committing such act rapist crosses the threshold of human being. According to Abu Hanifa a person who commits such act deliberately is liable for death punishment as Tazir119.He based his opinion on the narration of Hazrat Abdullah bin Abbas. Hazrat Abdullah bin Abbas(RA) narrates the saying of Holy PROPHET (SAW) that whoever deliberately commits sexual intercourse with the women of prohibited relation would be liable for death punishment120. According to Abu Hanifa if any man contracts marriage with women of prohibited relation and does not consider it wrong, he commits irtidad (apostasy), therefore, he would be liable for exemplary punishment as Tazir121. However, if he was ignorant then such sexual intercourse with prohibited relation does not amount to Zina but he would be liable for Tazir punishment that will be less than Hadd punishment122. Abu Yousaf and Muhammad, unlike Abu Hanifa, assert that he would be liable for the Hadd of Zina even though he know that a woman falls in the prohibited degree123. Imam Malik and Imam Shafi also share the opinion of Abu Yousaf and Muhammad124. However jurists are still grappling with the issue of coerced incest rape. It does not make sense that a person can commit such act with women of prohibited degree under coercion, not mentioning willful act. Only habitual offenders or those who have crossed the threshold of humanity commit such act. Therefore, Abu Hanifa's opinion seems to be more appropriate that such offendor must be sentenced to death as Tazir in order to protect the family system.

\section{Sexual intercourse with dead women (Necrophilia)}

119 Allama Gulam Rasool Saeedi ( n 44) 8:44.

120 Abu Jafar al-Tahawi, Sharah Maani al-Athar, Mawlana Shammas ud deen(ed) ( Maktabat ul Ilam Publishers Lahore 2012) 3:398. See also Musnad Imam Ahmed Bin Hanbal, Hadith no 2727.

121 Ibid 3:394.

122 Ibid 3: 396. See also Gulam Rasool (n 44) 8:47.

123 Ibid.

124 Ibid.

74 Indonesian Journal of Advocacy and Legal Services, Vol. 3 No. 1 (2021) 
Sexual intercourse with dead women has been occurring all over the world and an Islamic state is not immune from it. The corpse is not a thing to be desired because it generates feeling of disgust, let alone having coitus with it. Although, mere thought of committing such act induces nausea and loathing but a person who is in state of inceldom or in strong grip of taking revenge may commit such unnatural act without any feeling of disguise. In spite of the fact that such act was uncommon during the time of classical jurists, they did not shy away from discussing such unnatural act. However, whether the sexual penetration of a corpse constitutes a rape has never been settled by classical jurists. According to Abu Hanifa only a sexual intercourse with living women constitute Zina, hence, the culprit would not be liable for Hadd of Zina rather he would be awarded as Tazir punishment125. Malik and Shafi asserts that it is parallel to commit sexual intercourse with living women, thus, he would be liable for Hadd of Zina126. As, I have already stated that a normal person has no stomach to commit such act, only serial criminal and habitual rapist commit such act. Abu Hanifa gives a discretionary power to a ruler or judge to prescribe punishment for such offence. Therefore, Death punishment as Tazir or Syaysah seems to be appropriate punishment for such offender after taking into account the brain chemistry of the accused.

\section{Sodomy}

There exists a wide range of disagreement among classical jurists over Islam's position on homosexuality and anal intercourse. All jurists agreed that homosexuality or anal intercourse is a punishable offence. However, whether such act constitutes to Zina or not is a reason behind their disagreement over the issue of the punishment of this offense. The Hanfi School did not declare sodomy or anal intercourse to be Haddod crime127. Abu Hanifa was of opinion that sodomy (liwat) with a man or anal intercourse with women does not constitute Zina, hence, perpetrator or both would be liable for Tazir punishment128. However, Abu yousaf, Muhammad and Imam Malik considered sodomy with a man or anal intercourse with women to be an extension of the Hudood crime of Zina129.According to these jurists perpetrator should be punished in the same way as an adulterer. They were

\footnotetext{
125 Gulam Rasool (n 44) 8:45.

126 Syed Ameer Ali(ed), Fatawa Alamgiri (Maktabah Rehmania) $3: 255$.

127 Al-Kisani (n 107) 7:102.

128 Al-Marginani, (Al-Hidaya)Ayen ul Hidaya, Syed Ameer Ali(ed) (Maktabah rehmania 1992) 2:544.

129 Al-Kisani (n 107) 7:103.
} 


\section{S. Shahid}

of opinion that in this case perpetrator should be stoned if he is married and flogged if he is not married130. Imam Shafi took sterner position against the offender and prescribed death punishment as Syasha for the offender of sodomy.131 However, he was of opinion that if a man commit anal intercourse with women then he would be liable for Hadd of Zina132. Majority of classical and modern jurists agree that the evil consequences of sodomy (liwat) are among the worst of evil consequences; hence, its punishment must be one of the most severe of punishment. The Holy Prophet (PBUH) prescribed death punishment for a person who commits sodomy.133 It means that if a person coerces another person for sodomy he may be punished according to the opinion of Imam Shafi. However, the modern scholars may grapple with the issue when a woman is forced for anal intercourse. As jurists considered this act not more severe than sodomy, therefore, Imam Abu Hanifa's position seem to be appropriate that perpetrator is liable for Tazir punishment while women would be exempted from punishment. Abu Hanifa predicated his opinion on the saying of Holy Prophet (SAW) that: avoid flogging and applying the death penalty upon Muslim as much as you can134.

\section{Financial compensation and imprisonment}

Whether the convicted rapist has to pay a dower (Mahr) and financial compensation besides being awarding him sentence of Hadd penalty is another complex issue which modern jurists have to grapple with. Issue of imprisonment has also remained a center of dispute among classical jurists due to the fact that Holy Prophet (PBUH) imposed punishment of exile rather than imprisonment. It is reported by Zaid bin Khalid (RA) and Saeed bin Mussayib(RA) that Holy Prophet (PBUH) exiled the non-married fornicator for one year after awarding him Hadd punishment of Zina135. However, Abu Hanifa believed (Jassas writes) that punishment of exile was not Hadd rather as Tazir136. Abu Hanifa held that besides awarding Hadd punishment of lashes to unmarried rapist, it is the discretion of the ruler to determine whether or not fornicator is exiled but he is not liable to pay dower for unlawful sexual intercourse137. He further maintained that if rapist causes

130 Ibid.

131 Al-Marginani (n 128) 2:544.

132 Ibid.

133 Ibid. See also Musnad Imam Ahmed, Hadith no 2727. See also Sunan abu Daud, Hadith no 3362.

134 Sunan al-Kubra, Hadith no 15686. See also Abu Yousaf (n 22) 403.

135 Al-Bukhari, Jami al-Sahih, Hadith no 2314. See also Musnad Imam Ahmed bin Hanbal, Hadith no 16005.

136 Al-Jassas, Ahkam ul Quran ( Beirut: Dar ul Fikr n.d) 3:257.

137 Al-Thawi (n 120) 3:356. See also Imam Muhammad, Muwatta, 2:614.

76 Indonesian Journal of Advocacy and Legal Services, Vol. 3 No. 1 (2021) 
damage to her sex organ then he will be liable for one-third of diya; however, in case of pelvic floor dysfunction (complete damage of her sex organ and urinary tract) the rapist is liable to pay full diya.138 Abu Hanifa also asserts that if women dies due to the violence of rapist, perpetrator will pay full diya( blood money)besides being liable for Hadd penalty139. Similarly, Imam Muhammad also maintains that after imposing Hadd punishment of Zina, rapist would not be asked to pay dower140. However, majority of Malkiates and Shafiates hold that a rapist will also be liable to pay dower. Malik asserts that rape involves the right of Allah and the right of individual and these must be dealt with separately141. Imam Shafi held that besides paying dower a rapist is also liable to pay Arsh (monetary compensation for causing harm) if he has caused injury to the hymen of virginity and he would also be exiled for one year142. As far as issue of compensation for injury to prepubertal child girl is concerned, Sarakshi (Hanfiate jurist) asserted that besides paying dower perpetrator will be liable to pay one-third of diya for causing jurah jaifah(causing minor damage to her sex organ); however, in case of pelvic floor dysfunction (complete damage of her sex organ and urinary tract) of the victim, perpetrator is liable to pay full diya 143 .

Islam allows the victim to receive monetary compensation in case of injury. Women can receive monetary compensation if her hymen is ruptured but women who have an inborn lack of hymen or extra elasticity of hymen may be deprived from receiving monetary compensation. Therefore, Shafi's opinion is appropriate that victim must receive payment of dower irrespective of the fact whether hymen was ruptured or not; however, if hymen is ruptured then rapist would also be liable to pay financial compensation for causing harm to the hymen of victim. As financial compensation falls within Tazir punishment, therefore, a ruler or judge is only competent authority to determine the amount of dower and financial compensation for harm. As far as punishment of exile is concerned, majority of classical jurists believed that such punishment was imposed on unmarried fornicator during the time of Holy Prophet (PBUH). However, under international law no any state is authorized to revoke the nationality of its national unless he possesses dual nationality, hence, punishment of exile is impractical in modern states. Although, Islam does not prescribe

138 Syed Ameer Ali, Fatawa Alamgiri, (Maktaba Rehmania) 3:257.

139 Ibn Abidin, Hashiat Radd al Mukhtar (Beirur: Darul Fikr 387 AH) 4:30.

140 Imam Muhammad (n 111) 2:659.

141 Malik ibn Annas (n 6) 4:401.

142 Marginani, (Al-Hidaya) Sharha Hidaya, Alama Muhammad liaqat Ali Rizvi(ed) (Shabbir Brother Lahore 2012) 8:266.

143 Al-Sarakhsi, (n 18) 9:86. 


\section{S. Shahid}

imprisonment as punishment of fornication but prison facilities were also established during the time of Hazrat Umar (RA). It means sentence to imprisonment may be taken as an alternate to exile punishment. As, classical jurists unanimously agreed that punishment of exile is a Tazir punishment, so ruler/judge may determine the duration of imprisonment according to the modus operandi of crime and the previous criminal record of the rapist. Sentence to imprisonment is awarded in order to reduce the recidivism, therefore, awarding life imprisonment or languishing the non-habitual offender more than one year in prison tends to injustice both the victim and the accused because mere putting the accused behind the bar does not serve preventive as well as retributive function. Islam prescribes punishment of lashes to the rapist so he feels pain in whole body because by committing rape he had gratified his whole body. Moreover, Islam prescribes that an accused must be given an opportunity to mend his way of life after inflicting him corporal punishment. As Allah (SWT) says: Allah accepts the repentance (Toba) of those who do evil in ignorance and repent soon afterwards; to them Allah (SWT) turn in mercy 144.

\section{Appraisal}

It seems from the above discussion that majority of classical jurists assumed rape as a subset of Zina, therefore, they prescribed the punishment of rape same as that of Zina. According to them, however, a person who is coerced, whether man or women, is exempted from Hadd punishment of Zina. Majority of classical jurists stick to the point that Zina, whether forced or voluntarily, cannot be proved unless perpetrator confesses or four Muslim male eye witnesses give testimony. It means that evidentiary procedure to prove rape is same as that of Zina, hence, issue of proving rape has been remained a center piece of dispute among Muslim jurists. As proving rape through the testimony of four Muslim male eye witnesses who qualified the benchmark of Tazkia is near to impossible, therefore, we are left with three other options to convict the rapist. However, these three options also reflect some conflicting issues. According to minority of Muslim jurists Hadd punishment of Zina can be awarded to rapist on the basis of circumstantial evidence. Their opinion is predicated on the practice of Holy Prophet (PBUH) and the opinion of Imam Malik. During the time of Holy Prophet (PBUH) a women went out for offering the Fajar prayer. On the way she was raped. A group of Muhajreen reached at the place of incident after hearing the screaming of women. They caught a person and brought him before her. She

144 Al-Quran 4:17-18.

78 Indonesian Journal of Advocacy and Legal Services, Vol. 3 No. 1 (2021) 
said: "yes, he is an attacker". The accused was brought before the Holy Prophet (PBUH). When the Holy Prophet (PBUH) ordered that accused be stoned to death, the real culprit (who actually committed the act) stood up and said "I have committed such act with her". The Holy Prophet (PBUH) said to the women: "Go Allah has forgiven your mistake "145. This case tells that the accused was about to be stoned to death on the basis of circumstantial evidence. However, according to some scholar that punishment was under Syasah for which circumstantial evidence can be admitted. One thing that is clear from this case is that women was not awarded Hadd of Qadaf (slander) and the accused was about to be stoned to death on mere compliant of women. In Imam Malik's opinion pregnancy of unmarried women is sufficient prove of Zina unless she proves that she was raped or is married. Malik's opinion, to some modern Muslim scholar, implicitly states that in the presence of circumstantial evidence perpetrator of rape can also be awarded Hadd of Zina.

However, majority of Muslim jurists consider that rapist cannot be awarded Hadd of Zina mere on the basis of circumstantial evidence, according to them; perpetrator is not liable for Hadd of Zina unless four pious Muslim male eye witnesses testify the actual act of intercourse or perpetrator confesses in four different court meetings. Therefore, in order to bring the jurists of all school of thought on the same page it is suggested that in case perpetrator evade Huddod punishment, he may be prosecuted under Tazir or Syasah.

Before delving into further discussion it is crucial to elaborate the nature of Tazir and Syasah offence. Some Muslim jurists especially ibnNujaym wrongly presumed that as Tazir is pure right of individual, therefore an accused cannot be punished under Tazir offence unless two man or two women with one man give testimony against the offender146. However, it is suggested that under Islamic Criminal Justice System Tazir and Syasah are used as inter changeably. For instance, Qisas is joint right of Allah and the individual but right of individual is pre-dominated. The Holy Quran reads: "Whosoever killed a person without (any reason like) man slaughter, or corruption on earth, it shall be as if he had killed all mankind"147. Similarly at another place the Quran reads: "and there is life for you in the retaliation, o men of understanding, that you may guard yourselves148. These verses clearly indicate that killing person unlawfully violates the right of community

145 Musnad Imam Ahmed bin Hanbal, Hadith no 27782.

146 Ibn Nujaym, al-Ashbah wal-Nazair (Beirut: Darul Kutub al-Ilmia n.d) 152.

147 Al-Quran 5:32.

148 Al-Quran 2: 179. 


\section{S. Shahid}

as well. For instance, killing any person (unlawfully) endangers the survivor of whole community. In this way, even if it is accepted that two male witnesses are required to convict the perpetrator under Tazir offence and the ruler is unable to manage two male eye witnesses. In spite of this, the ruler will be authorized to punish the perpetrator under Syasah offence (to save the community right) on the basis of circumstantial evidence or the complainant of victim alone. Abu Yousaf was also of opinion that evidence of one person is sufficient for the ruler to convict the murderer149. (This paper is not meant to discuss Tazir or Siyasah at length). Therefore, it is save to suggest that Islamic criminal justice system permits the ruler to convict the offender under Tazir or Siyasah without out relying on two Muslim male eye witness rather circumstantial evidence or complaint of victim alone will be sufficient to punish the offender.

However, some issues which are related to punishment of rape under Tazir/Syasah may become cause of dispute among Muslim jurists. All jurists agreed that Tazir punishment of lashes must not exceed Hadood punishment. Their reason is based on the saying of Holy Prophet (PBUH) that number of lashes must not exceed those for Hudood offences150. There is no disagreement among jurists regarding death penalty as Tazir/Syasah, however, they do not see eye to eye regarding issue of maximum number of lashes that may be inflicted on an offender as Tazir/Syasah. Imam Abu Hanifa and Imam Shafi have made consensus that rapist may be awarded death punishment as Tazir/Syasah. However, there disagreement exists over the issue of lashes. According to Abu Hanifa and Imam Mohammad the punishment of lashes under Tazir must not exceed 39 lashes151. Imam Yousaf was of opinion that punishment of lashes must not exceed 79 lashes as Tazir whereas Hanbliate jurist permit 99 lashes for sexual offender as Tazir 152. Thawi asserts that as the saying of Holy Prophet(PBUH) indicate that lashes may equal to Hudood but not exceed the Hudood punishment, therefore offender may be awarded 100 lashes as Tazir153. He based his opinion on the story of Nauman bin Basher and Umar bin Shoaib. A Woman told Nouman bin Basher that her husband had committed Zina with her slave girl. She requested from Nouman that her case must be decided on the Sunnah of Holy Prophet (PBUH). Nouman said that if you had allowed (HALAL) he to commit such act then he would be awarded 100 lashes154.

149 Abu Yousaf (n 22) 405.

150 Al-Marginani (n 142) 8:415.

151 Ibid 8:414.

152 Ibid 8:413. See also Abu Yousaf (n 22) 442

153 Al-Thawi (n 120) 3:387.

154 Ibid. See also Musnad Imam Ahmed Bin Hanbal, Hadith no 18090.

80 Indonesian Journal of Advocacy and Legal Services, Vol. 3 No. 1 (2021) 
Thawi also narrates the narration of Umru bin Shoaib. According to Umru bin Shoaib a person murdered his servant. The accused was brought before the Holy Prophet (PBUH). The Holy Prophet (PBUH) awarded him punishment of 100 lashes.155 According to Thawi these 100 lashes in both cases were as Tazir. Therefore, it is save to presume that if 100 lashes are awarded as Tazir then same lashes may be awarded as Syasah, and if Tazir must not exceed Hudodd then Syasah would also not exceed Hudood.

We reach to the conclusion; besides incorporating rape under Hudood offence it may also be included under category of Tazir/Syasah offences in order to avoid strict evidentiary procedure to prove Zina. However, if rape is incorporated as Hirabah offence it will also require two Muslim male eye witnesses to prove the Hirabah. Thus following the insightful story of 'An Arab and his Camel' it is better that rather than relying on strict evidentiary procedure of Hudoods latest medical advancements should be utilized to convict the rapist under Tazir/Syasah offence rather than incorporating it under Hadd of Hirabah. Moreover, in this way circumstantial evidence or complaint of the victim alone would be sufficient to convict the rapist. However, the question arises here: whether or not victim is liable for Hadd of Qadaf if she accuses any person but could not manage four Muslim male eye witnesses. The Holy Quran reads: "that Allah does not like that the evil should be uttered in public except by him who has been wronged"156. Hence, the victim of rape has been allowed to complaint without any fear of Hadd of Qadaf. Besides awarding the perpetrator life imprisonment and death penalty, he may be awarded punishment of lashes not exceeding 75 (following the practice of Hazrat Ali (RA)) as Tazir/Siyasah. In this mechanism, although victim may pardon the offender but his waiver remain ineffective as long as the ruler does not pardon the offender. Similarly, the ruler cannot pardon the offender unless the victim has pardoned him. It is suggested that it seems better that non-habitual offender be awarded punishment of lashes under Tazir/Syasah which may be 75 lashes, however, remaining 25 lashes may be offset with increasing the severity of lashes or imprisonment. It is because, in Tazir /Syasah number of lashes must not exceed to Huddod but their severity may be increased157. Awarding punishment of lashes would serve both retributive as well as preventive function. Therefore, rather than keeping the perpetrator behind the bar, he must be provided one opportunity after awarding him punishment of lashes. However, besides lashes he may be awarded sentence to imprisonment which should not be more than one year

155 Al-Thawi (n 120) 3:366.

156 Al-Quran 4:148.

157 Al-Marginani (n 142) 8:414.

Indonesian Journal of Advocacy and Legal Services, Vol. 3 No. 1 (2021) 


\section{S. Shahid}

for non-habitual offender. However, an habitual offender and a person who commit gang rape or rape with minor should be awarded death penalty or life imprisonment as Tazir/ Syasah.

\section{National Responses Toward Rape}

1. Changing Societal and Religious Attitude

Our entrenched social and religious beliefs are the main reason behind the under reporting of rape crime, hence, low conviction rate. Rapes myths continue to prevail in our society. Rape myths are beliefs that are generally false but widely held, and that serve to justify male aggression against women158. Rape victims are often blamed for provoking the incident; therefore, many victims of rape stay silent in order to avoid public humiliation. Our society considers the loss of virginity by any means to be ruining marriage prospects. Many religious scholars hold view that any sexual act should not be part of public discourse, according to them, openly discussing rape will affect the public morality.

Education and media can be proved best tools to change our social and religious attitude toward rape victim. Commercialization of women's body produces an idle environment for rape. Although, media regulations have been developed, many media companies do not shy away from airing provocative content. However, if electronic and social media is used in an innovative way, they have potential to bring the issue of rape into the public discourse in order to fight the social stigma associated with victim of rape. Our religious scholar must abandon notions forcing victim of rape to stay silent in order to preserve public morality. Public order cannot be preserved unless perpetrator is given exemplary punishment; therefore, Allah (SWT) allows the wronged to openly mention his ordeal159. The Quran also commands that punishment of fornicator and adulators be carried out in front of crowd. Societal attitude can change with the help of media and education, but media and education alone cannot prevent the rapist to rape and victim to be raped. However, education and media can inculcate confidence in the victim to speak out about her ordeal.

\section{Efficient forensic examination and investigation}

The quality of investigation has a critical impact on the prosecution of crime. Police deliberately miscode thousands of rape cases so they do not have to conduct full investigation on then. The victim and family of victim often

158 Lonsway and Fitzgerald, Rape myths: in Review, psychology of women quarterly,v 18,issue $2,1994$.

159 Al-Quran 4:148.

82 Indonesian Journal of Advocacy and Legal Services, Vol. 3 No. 1 (2021) 
have to face humiliation in police station. Poor police record keeping and corruption contribute to the loss of evidence and inefficient investigation. The forensic examination is crucial to secure evidence to corroborate the victim's version of the event. Our law enforcement agencies are not adept at collecting forensic evidence. Our forensic laboratories lack modern equipment, technique and experts. The determination of penetration is often conducted by outdate and disgraceful technique.

Forensic laboratories should be established in accordance with modern international standard and technique. Our government can enter into arrangement with the UK and the USA to train personnel in our forensic department. Only female forensic medical examiner should examine the rape victim because victim does not feel comfort in letting her body be examined by a male physician. Special rape courts and rape investigation department should be established in every district to prosecute and investigate rape crime. Rape investigation department must be given operational independence so police conduct investigation without any political interference.

\section{Dar ul Amaan}

In many developed countries special rape crisis center have been established that offer expert provisions to the victim. These centers may help rape victims through investigation, medical examination and cross examination. These center may provide shelter to homeless victim and may be crucial in meeting emergency needs including food, clothing, medical and psychological counseling. These shelters may be proved crucial in reintegrating of rape victim in society.

\section{Health facilities to victim}

Rape may result in pregnancy, gynecological impacts, trauma, bleeding, infection, pain, genital irritation, urinary tract infection, pelvic pain, decreased sexual desire and hepatitis B and HIV160. The government must sure that anti-retroviral drugs or Post exposure prophylaxis available to rape victim to prevent transmission of sexually transmitted disease. Rape may results in suicide thoughts and suicide attempts. The government must sure the availability of specialized services for victim of rape with in health care system that addresses both mental and physical injuries. According to the report of the WHO, the harms from rape have important impacts for

160 Rachel Jewkes , 'Preventing Domestic violence: Most Women Welcome Inquiries , But Doctor and Nurses Rarely Ask About it', 324 (7332) 2002 BMJ 253-254. 


\section{S. Shahid}

women's morbidity and mortality.161 In Pakistan health services designated as specially for rape victim may pose risks of further violence against victim, therefore, it is necessary that information about victim remain under the ground and health services should offer privacy and confidential.

\section{Reform in substantive law}

Although anti-rape laws have been enacted to prevent the victim from being re-victimized during investigation and cross examination but wide discrepancies still exist between 'law as legislation' and 'law in practice'. The victim's character assassination or sexual history may be discussed in open court. The victim may be forced to recount her experience during trial that is why many victims withdraw their cases at this stage because of such secondary victimization.

It is an undeniable fact that our laws are outdated, discriminatory and ambiguous. For instance, under section 375(5) of Pakistan penal code (PPC) 1860 , a person is said to have committed rape when he had sexual intercourse with a girl or women, with or without her consent, if she is under the age of 16 year. Many would argue that puberty, and not law, indicate the age of consent, which make things very problematic. Since voluntarily fornication has been decriminalized in majority of non-Muslim countries, therefore, accused of rape crime in these countries can use consent of victim to avoid allegation of rape. However, it does not make senses why consent clause acts as a protective shield for the accused in a country where voluntarily fornication is a criminal act, and moreover, in Islam punishment of fornication and rape is same. DNA can prove the occurrence of crime but existence of DNA cannot prove or disprove consent. Similarly, if the medical report shows that the victim's vagina can admit two fingers without pain, then it is presumed that the victim is a woman of easy virtue and thus might have given consent. These ambiguities in consent clause lead the defense counsel to misconstrue consent as a defense.

Under section 375 of PPC, penetration is sufficient to constitute sexual intercourse. This section does not reflect the Islamic line of thinking. In Islamic law forced sexual intercourse which constitutes Zina can only be regarded as rape, therefore, penetration other than penis of male does not constitute rape. Under Islamic law, forced penetration of woman's internal reproductive organ can only be regarded as rape. As penetration alone cannot constitute rape, in order to make the existing laws in line with Islamic law, penile or object penetration of women's orifices other than vagina should be

161 World Health Organization, 'Understanding and Addressing violence Against Women', Pan American Health Organization. 
included under a new category of 'Sexual assaults other than Rape' and incorporated into PPC. (Other substantive issues have been discussed in section 2 and appraisal of this paper)

\section{Improving socio economic position of women}

Violence against women is not only a consequence of gender inequality; it also perpetuates the gender gap. There is strong link between economic position of women and her vulnerability to be raped. Women whose access to economic resources is limited are more vulnerable to rape because her weak economic position restricts her to avoid vulnerable situation. A lack of economic resources often forces women to stay silence after such act in return of money. Economic position of women cannot be ameliorated unless women is educated and empowered. The government can enhance the economic position of women by establishing school in every village. In this way more female teacher and female doctor would be available, hence, less chance for women to be raped by male teacher and doctor. The government must sure that women would not be deprived from inheritance. Most of our GDP consist of informal economy, it is high time for government to formalize the informal economy so rural women get their fair share from contributing in economy. A well-educated and economically well-off women would not capitulate her dignity to the social stigma and entrenched beliefs of society, rather she does fight her case to the end and would be in better position to protect her and her children from being trapped in the plot of criminals.

\section{E. Conclusion}

Rape is a difficult crime to investigate and prosecute in any country. It is quality of criminal justice response that ensures the protection of women from sexual beasts and the accountability of the perpetrators. Fact based policies and measures, coupled with making the existing law in line with Islamic law would act both preventive as well as punitive instrument. Therefore, it is high time that the perpetrator of such act must be awarded strict punishment that serves preventive as well as retributive function rather than mere putting him behind the bar. 


\section{F. Acknowledgments}

None

\section{G. Declaration of Conflicting Interests}

The authors state that there is no potential conflict of interest in the research, authorship, and/or publication of this article.

\section{H. Funding}

None

\section{References}

Abd al Aziz ibn Ahmed Bukhari, kashf al Asrar an Usul Fakr al Islam al Bazdawi, Abdullah Muhammd Umar(ed), (1 ${ }^{\text {st }}$ ed, Beirut: Dar ul kutub al ilmiya, 1997)

Abd al Razzaq ibn Hammam al Himyari, Al Mussanaf (Beirut: Dar ul kitab al-ilmiya 2000)

Abd al-Jabbar Ibn Ahmed Ibn Abd Al-Jabbar Al-Hamadani (935-1025 AD) a Mutazilite Theologian and follower of Shafi school, Al-Mugni Fi Abwab Al-Tawhid Wa Al Adl . edited by Taha Hussain and Ibrahim Madkur(ed) (Cairo: Wizarat al-Thaqfa wa al-Irshad al-Qawmi, Al Idara al Amah lil Thaqafia 1960-9)

Abi Sahl Abu Bakr al-Sarakhsi, al-Mabsut (Beirut: Dar ul_kutab al-ilmia 1997)

Abu Bakar Ahmed Al-Razi Al-Jassas, Ahkam al-Quran, Abd al Salam Muhammad Ali Shahin(ed) (Beirut: Darul Kutub al-ilmiyya, n.d)

Abu Daud Sulaiman bin Al Ashath Bin Ishaq al Sajistani, Sunan abu Daud, Hadith no 2177, Vol 3 (Damascus: Dar ar Risalah al-Alimah 2009)

Abu Daud Sulaiman Ibn al-Ashatal Sijistani, Sannun abi Dawood, Muhammad Muhyi al-din Abd al-Hamid(ed) (Cairo: Dar ul Fikr 1980)

Abu Hamid Imam Muhammad Gazali, Ahya ul Uloom, Faiz Ahmed Awaisi(ed) (Lahore: shabbier Brothers)

Abu Jafar al-Tahawi, Sharah Maani al-Athar, Mawlana Shammas ud deen(ed) (Maktabat ul Ilam Publishers Lahore 2012)

Abu Yousaf, Kitab al-Khiraj, Niaz ahmed Okarwi (ed) (Maktaba Rehmania)

Ahmed bin Hanbal, Musnad Imam Ahmed bin Hanbal, Abbas Anjum and other(eds) (Ansaar Al Sunnat Publicationers n.d)

Al Bahuti, kashf al Qina, (Beirut: Dar Ul-Fikr 1412 AH) 
Al Bukhari Muhammad ibn Ismail, Al Jami al Sahi, Hadith no 6827 (Cairo: al-Maktaba al-Salafia, 1400AH).

Al Bukhari Muhammad Ibn Ismail, Al Jamia al Sahih, Hadith no 6594 (Cairo: Al-Maktaba al-Salafia, 1400AH)

Al Dardi Abu Al Barkat Ahmed ibn Muhammad, Sharh Mukhtasar khalil (Cairo: Dar Al-Maarif 1986)

Al Jassas Abu Bakar Ahmed Ibn Ali, Sharh Mukhtasar al Tahawi Fi al-Fiqh al-Hanfi, Ismat ullah Inayat(ed) (1 ${ }^{\text {st }}$ edn, Beirut: Darul Bash aer-al Islamiyah lil Tiba a wa al Nashr wa al-Tawzi 2010)

Al Ramli Shamas al Din Muhammad, Nihayat al-Muhtaj ila Sharah al Minhaj (Cairo: Matba Mustafa Al Halabi 1938)

Al Sarakshi, Kitab al Mabsut, Abu Abd ala Muhammad Hasan Ismail al-

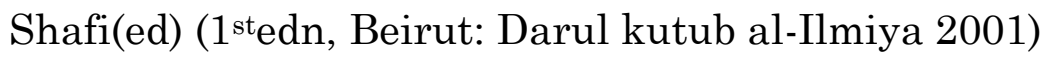

Ala al-Din al-Kasani, Badai al-Sanai Fi Tartib al-Sharia, Dr Mehmood Ul Hassan(ed) (Hatif Art Press Lahore, 1997)

Al-Bahuti, kashf ul Qana (Beirut: Darul Kutub al-ilmiyyah, 1983)

Al-Bahuti, Sharh Muntaha Al-Iradat (Madina: al-Maktaba al-Salafia n.d)

Al-Baihaqi, Al-Sunan al-Kubra, Hadith no 14714 (3 ${ }^{\text {rd }}$ edn, Beirut: DaralKitab al-Ilmia 2003)

Al-Bayhaqi Abu Bakar Ahmed Ibn Hussain Ibn Ali , Sunnan al-Kubra lilBayhaqi ( Dara tul Marif, 1925) 8

Al-Jassas, Ahkam ul Quran ( Beirut: Dar ul Fikr n.d)

Al-Juwayni Dhia ul Din Abd al Malik Ibn Yusuf, al-Burhan Fi Usul ul-Fiqh, Abd al-Azam al-Dib(ed) (1 ${ }^{\text {st }}$ edn, Qatar: jamia Qatar 1979)

Al-Kasani Ala Al Din Abu Al-Hassan Ali Ibn Sulaiman, Bada'I Al Sanai Fi Tartiba al Sharai (2nd edn, Beirut: Dar ul-Kitab Al-Arabi 1982).

Al-Marginani, (Al-Hidaya)Ayen ul Hidaya, Syed Ameer Ali(ed) (Maktabah rehmania 1992)

Al-Quran

Al-Ramli, Nihayat al-Muhtaj (Beirut: Dar ul Kutab al Ilmia 1993)

Al-Suyuti Jalal al Din Abi Bakar, al-Ashbah wal-nazair (Beirut: Dar al Kitab al-Arabi 1987)

Asifa qureshi ,'Her Honour:an Islamic critique of the rape provisions in Pakistan's ordinance on Zina (kuala lampur : Islamic book trus 2002)

Baqillani Abu Bakar Muhammad Ibn al-Tayyib, al-Taqrib Wa al-Irshad alSaghir, Abd al-Hamid ibn Ali Abu Zunyad(ed) (1 ${ }^{\text {st }}$ edn, Beirut: Muassasat al-Risalah 1993-1998)

Burhan al-Din al-Farghani al-Marghinani, (al-Hidaya)Ahsan ul Hidaya, Mufti Abdul Haleem Qasmi(ed) ( little Star Printers Lahore 2004)

Deuteronomy 22:23-25, //https:www.blogs.timesofIsrael.com/the-torahmarry-your-rapist-law.

Gulam Rasool Saeedi, Tibiyyan ul Quran ( Roomi Publishers and Printers Lahore 2013) 
Ibn al-Arabi Muhammad ibn Ahmed, Ahkam al-Quran (Cairo: Isa al-Hlabi 1958)

Ibn Abidin, Hashiat Radd al Mukhtar (Beirur: Darul Fikr 387 AH).

Ibn Abidin, Minhat al Khaliq (Beirut: Darul Kitab al-Ilmiya 1997)

Ibn Hazm Abu Muhammad Ali ibn Ahmed, Kitab al-Muhalla bil Athar (Beierut: Darul Kutub al-Ilmiyya 1988)

Ibn Hazn, al-Muhallah (Beirut: Darul kutub al Ilmia 1988)

Ibn Juzayy abu al-Qasim Muhammad ibn Ahmed al-Kalbi, Al Qawanain Al Fiqhiyya, Muhammad Amin al-Dinawwi(ed) (Beirut: Darul Kutub alilmiyya, 1998)

Ibn Majah Abu Abdullah Muhammad Ibn Yazid Ibn Majah, Sunnan ibn Majah (Beirut: Darul Kutub al-ilmiyya, 1998)

Ibn Nujaym, al-Ashbah wal-Nazair (Beirut: Darul Kutub al-Ilmia n.d)

Ibn Qudamah, al-Mugni (Cairo: Matba Al imam, 1964)

Ibn Qudamah, al-Mugni ala Mukhtassar al-Kharaqi (Cairo: Darul Kutb al-Ilmiyyah 1994)

Ibn Taymiyyah, Al Ikhtiyarat Al Fiqqiyyah Min Fattawa Ibn Taymiyyah, ( available at https://www.quoro.com/what-islams-stance-on-maritalrape.

Ibn-Nujaim, Al Isbhah wa al Nazair fi al fiqh al Hanafi (karachi:Qadimi Kutab Khana)

Ibn-Qudamah al-Maqdisi Muwaffaq Al Din Abu Muhammad, al-Mugni (Beirut: Dar al Fikr 1405 AH)

Imam Ahmed bin Hanbal, Musnad Ahmed bin Hanbal

Imam Malik bin Anas, Muwatta, Allama Abdul Hakeem Akhtar (ed) (Fareed Book Stall Lahore)

Imam Muhammad Hassan Shaybani, Muwatta, Allama Muhammad Ali(ed), (Roomi Publishers and Printer Lahore 2005)

Imam Muhammad Hassan Shaybani, Sharh Muwatta Imam Muhammad, Muhammad Ali(ed) (Freed Book stall Lahore)

International Approaches to Rape, Breaking the Silience :Rape law in Iran and Controlling and Women's Sexuality (2011) Briston University Press.

Ismail Muhammad Bakar, Al Fiqh al Wadih Bayan al Kitab Wa al Sunnah (Cairo: Dar Ul Manar 1990)

Lonsway and Fitzgerald, Rape myths: in Review, psychology of women quarterly,v 18,issue 2, 1994.

Malik Ibn Anas bin Malik bin abi Amir, Al Mudawwana Al-Kubra (Cairo: Marba'at al-sa'ada,1905)

Mansur Ibne Younus Ibn Idris al Bahuti, Sharah Muntha al Iradat (Madina: Al Maktaba al Salafia n.d )

Marginani, (Al-Hidaya) Sharha Hidaya, Alama Muhammad liaqat Ali Rizvi(ed) (Shabbir Brother Lahore 2012) 
Mawlana Aftab Ali, Fatah al Waqayah li hal Sharah al Waqayah (Kutab Khana Makki)

Muhammad Amin Ibn Umar Ibn Abideen, Hashiat Rad al Mukhtar (Beirut: Dar Ul Fikr 1836)

Muhammad Ibn Idris Al Shafi, Kitab al- Umm (Cairo: Dar al Shab 1321 AH). Muhammad Nasir al din al-Albani, Daif Abi Dawud, (Beirut: Al-Maktab alIslami $1412 \mathrm{Ah})$.

Mussanaf ibn abi shybah, Hadith no 29013 available at $</ /$ https:www.abuaminaelias.com/there-is-no-theology-of-rape-inislam>accessed on 8 Oct 2020.

Rachel Jewkes , 'Preventing Domestic violence: Most Women Welcome Inquiries , But Doctor and Nurses Rarely Ask About it', 324 (7332) 2002 BMJ 253-254.

Sayyid Sabiq, Fiqh as sunnah (3rd edn, Beirut: Darul Kutub al-Arabi 1997)

Sharah al Nawawi, Sharh Sahi Muslim 1456 (available at Abu Amina Alias, There is no theology of rape in Islam, Faith in Allah, August 20,2015 https://abuaminaelias.com/no-theology-of-rape-in-isalm/ accessed on 8 Oct 2020 .

Sunan ibn Majah, Hadith no 2043, https://abuminaelias.com/dailyhadithonline2012/4/10Allah-forgivemistake-coercion, accessed on 8 Oct 2020.

Wahbah al-Zuhayli, Al Fiqh Al Islami Wa Adallatuhu (2nd edn, Damascus: Dar Al Fakr 1985)

Wahbah uz- Z | uhayli, Al-Fiqh al Islami Wa Adilataha, (4th edn, Damascus: Darul Fikr 1997)

World Health Organization, 'Understanding and Addressing violence Against Women', Pan American Health Organization.

\section{ABOUT AUTHOR(S)}

Shahzeb Shahid is a graduated from the Faculty of Law, Punjab University Pakistan. His area of research is analyzing contemporary international development, domestic laws, and modern scientific advancements under the light of Islamic Jurisprudence. 


\section{Quote}

Rape is one of the most terrible crimes on earth and it happens every few minutes. The problem with groups who deal with rape is that they try to educate women about how to defend themselves. What really needs to be done is teaching men not to rape. Go to the source and start there.

\section{Kurt Cobain}

